\title{
PERAN KEPUASAN KONSUMEN DALAM MEMEDIASI PENGARUH KUALITAS LAYANAN TERHADAP MINAT BELI KONSUMEN UNTUK MENGGUNAKAN JASA MASKAPAI PENERBANGAN AIR ASIA
}

Yohanes Febrianto

Institut Bisnis dan Informatika Kwik Kian Gie

Tumpal J. R. Sitinjak

Institut Bisnis dan Informatika Kwik Kian Gie

tumpal.janji@kwikkiangie.ac.id

\begin{abstract}
In this fast-paced era, high mobility has become necessity for people. They need a fast, simple and cheap transportation.Low cost airlines be an option for people to support their needs. One of the airlines service provider that have low cost concept is Air Asia.This research aims to study the effect of service quality on Air Asia customer purchase intention mediated by customer satisfaction.This research use non-probability sampling with judgement approachment method to collect the data, that the respondent ever used the Air Asia service provider at least once a time. This research collect the data from 150 respondent. The data is collected by the questionnaire and tested by SEM (structural equation modeling) with Lisrel 8.80. The result of this research is there are significant effect between service loyalty and customer satisfaction on customer purchase intention partially and there is a significant effect between service quality on customer purchase intention mediated by customer satisfaction.
\end{abstract}

Keywords: Service Quality, Customer Satisfaction, Customer Purchase Intention

\begin{abstract}
ABSTRAK
Dijaman yang serba cepat ini kebutuhan akan mobilitas yang tinggi menjadi sebuah kebutuhan pokok bagi masyarakat. Masyarakat membutuhkan sebuah transportasi yang cepat, mudah, dan murah. Penerbangan berbiaya rendah menjadi pilihan bagi masyarakat untuk kebutuhan mereka. Salah satu maskapai yang memiliki konsep berbiaya rendah adalah Air Asia. Penelitian ini bertujuan untuk mempelajari apakah terdapat pengaruh antara kualitas layanan terhadap minat beli konsumen untuk menggunakan jasa masakapai penerbangan Air Asia yang dimediasi oleh kepuasan konsumen. Penelitian ini menggunakan metode non-probability sampling dengan pendekatan judgement sampling, dimana responden yang berpartisipasi merupakan konsumen yang pernah menggunakan jasa maskapai penerbangan Air Asia. Responden dalam penelitian ini berjumlah 150 orang. Metode pengumpulan data menggunakan kuesioner, lalu data diolah dengan analisis SEM (structural equation model) dengan aplikasi Lisrel 8.80. Hasil dari penelitian ini adalah terdapat pengaruh yang signifikan antara kualitas layanan dan kepuasan konsumen terhadap minat beli konsumen secara parsial dan terdapat pengaruh signifikan antara kualitas layanan dengan minat beli konsumen yang dimediasi oleh kepuasan konsumen.
\end{abstract}

Kata Kunci: Kualitas layanan, kepuasan pelanggan, keinginan membeli.

\section{PENDAHULUAN}

Pada jaman yang serba cepat ini, mobilitas yang tinggi merupakan sebuah kebutuhan yang tidak dapat dihindari oleh masyarakat. Masyarakat membutuhkan transportasi yang mudah, cepat, dengan biaya yang terjangkau untuk menunjang mobilitas mereka. Sebelumnya masyarakat menggunakan alternatif transportasi darat dan laut, namun hal ini sangat menguras waktu. Untuk itu masyarakat memilih altrnatif lain yaitu menggunakan transportasi udara, akan tetapi harga yang ditawarkan sangat mahal sehingga tidak semua orang dapat menikmati layanan maskapai penerbangan.

Seiring dengan perkembangan jaman, layanan maskapai penerbangan dengan biaya yang terjangkau dapat diwujudkan. Maskapai yang mengusung penerbangan 
berbiaya rendah atau low cost airlines memiliki beberapa karakteristik utama, yaitu menggunakan satu pesawat untuk satu jenis kelas penerbangan, penggunaan pesawat dengan intensitas yang tinggi, tidak terdapat layanan makanan atau minuman (no frill), menerapkan nilai lindung bahan bakar secara agresif, dan membatasi layanan penumpang khusus (Avipedia, 2011). Hal ini menarik animo masyarakat untuk menggunakan jasa maskapai penerbangan guna menunjang kebutuhan mobilitas mereka yang tinggi. Pada saat ini pesawat tidak hanya digunakan untuk melakukan perjalanan liburan, akan tetapi pesawat sudah menjadi sebuah kebutuhan bagi para pebisnis yang akan melakukan pertemuan bisnis di luar kota. Peningkatan kebutuhan masyarakat akan pesawat menjadi sebuah peluang yang menarik bagi pemasar untuk dapat meraih pangsa pasar yang besar.

Salah satu maskapai yang memiliki konsep biaya rendah atau low cost airlines yang berkembang di Indonesia adalah Air Asia. Maksapai penerbangan Air Asia merupakan sebuah masakapai penerbangan asal Malaysia yang mengusung penerbangan dengan biaya yang murah dan menjelma menjadi sebuah fenomena yang menarik di pangsa pasar Asia Pasifik. Harga yang ditawarkan oleh maskapai penerbangan Air Asia tergolong sangat murah dan berada dibawah semua pesaingnya. Air Asia kerap memberikan berbagai promo penerbangan ke berbagai destinasi yang mereka layani. Promo yang diberikan biasanya pada musim liburan (pertengahan tahun), pasa saat lebaran maupun akhir tahun. Dalam beberapa kali promonya Air Asia memberikan harga kursi gratis bagi beberapa pemesan pertama yang beruntung, untuk tujuan penerbangan tertentu.

Oleh karena harga yang tergolong cukup murah dengan berbagai promo yang ditawarkan dan destinasi penerbangan yang cukup variatif, Air Asia mampu meraih pasar yang cukup besar di Indonesia. Bahkan dengan berbagai penghargaan yang diraih, diantaranya menjadi maskapai penerbangan berbiaya rendah terbaik di dunia 8 kali berturutturut menurut versi skytrax, Air Asia menjadi maskapai berbiaya rendah terbesar se-Asia Pasifik. Namun, terkait dengan harga murah yang ditawarkan kualitas layanan menjadi sebuah faktor penentu yang mempengaruhi konsumen untuk memilih sebuah maskapai penerbangan.

Kualitas layanan menjadi sebuah pertimbangan penting bagi konsumen untuk memilih jasa yang akan mereka gunakan. Keseluruhan kinerja yang dihasilkan oleh perusahaan tersebut menjadi sebuah tolak ukur baik atau tidaknya kualitas layanan dari sebuah jasa 
yang diberikan. Hal tersebut akan memiliki dampak langsung terhadap kepuasan yang akan dirasakan oleh konsumen. Apabila kualitas layanan yang ditawarkan baik dan kebutuhan konsumen dapat terpenuhi, maka akan tercipta sebuah kepuasan konsumen. Sebuah kepuasan mucul dari berbagai macam hal yang timbul dari konsumen, diantaranya adalah adanya kebutuhan yang menuntut untuk dipenuhi, ekspektasi konsumen terhadap sebuah kualitas yang dipersepsikan, dan kinerja sebuah kualitas yang akan menciptakan kepuasan tersebut (Oliver, 1997). Oleh karena itu, untuk meraih sebuah keberhasilan pemasar perlu memahami apa yang sebenarnya dibutuhkan oleh konsumen dengan baik.

Selain itu, kualitas layanan juga memiliki dampak terhadap pilihan konsumen untuk menentukan jasa yang akan mereka gunakan. Apabila kualitas layanan yang diberikan baik dan memberikan sebuah kepuasan, konsumen akan memiliki minat yang tinggi untuk mengkonsumsi jasa tersebut. Namun, sebaliknya apabila kualitas jasa yang ditawarkan oleh konsumen tidak baik, maka hal tersebut akan mempengaruhi minat beli konsumen untuk menggunakan jasa tersebut. Pemahaman konsep mengenai minat beli konsumen dan kepuasan menjadi sebuah hal yang saling berhubungan, karena minat beli yang timbul dalam perilaku konsumen akan sangat dipengaruhi oleh kepuasan yang dirasakan. Konsumen yang memiliki rasa puas akan cenderung melakukan pembelian ulang terhadap jasa yang sama. Bahkan menurut penelitian yang dilakukan oleh Handayani dan Irianto (2011) menyatakan, bahwa kepuasan yang dirasakan konsumen mempengaruhi minat beli konsumen terhadap sebuah barang atau jasa. Konsumen yang merasa puas cenderung memiliki minat beli yang tinggi pada pembelian di masa yang akan datang.

Kualitas layanan yang diberikan suatu perusahaan menjadi sebuah penentu bagaimana sebuah perusahaan jasa dapat menjaga eksistensinya. Perusahaan harus memberikan kinerja layanan dengan kualitas yang baik agar dapat memenuhi apa yang dibutuhkan konsumen. Dengan terpenuhinya kebutuhan konsumen maka akan tercipta kepuasan konsumen yang merupakan interpretasi dari sebuah kualitas layanan, yang akan menjadi faktor penentu tinggi atau rendahnya minat beli konsumen untuk menggunakan jasa tersebut. Hal ini yang mendasari diangkatnya tema pengaruh kualitas layanan terhadap minat beli konsumen yang dimediasi oleh kepuasan konsumen.

\section{Rumusan Masalah:}


1. Bagaimana kualitas layanan maskapai penerbangan Air Asia menurut konsumennya?

2. Apakah konsumen merasa puas setelah menggunakan jasa maskapai penerbangan Air Asia?

3. Seberapa besar minat beli konsumen untuk menggunakan jasa maskapai penerbangan Air Asia?

4. Bagaimana pengaruh kuaitas layanan maskapai penerbangan Air Asia menurut konsumennya?

5. Bagaimana pengaruh kualitas layanan terhadap minat beli konsumen untuk menggunakan jasa maskapai penerbangan Air Asia?

6. Bagaimana pengaruh kepuasan konsumen terhadap minat beli konsumen untuk menggunakan jasa maskapai penerbangan Air Asia?

7. Bagaimana pengaruh kualitas layanan terhadap minat beli konsumen untuk menggunakan jasa maskapi penerbangan Air Asia yang dimediasi oleh kepuasan konsumen?

\section{Tujuan Penelitian:}

1. Untuk mengetahui bagaimana kualitas layanan maskapai penerbangan Air Asia menurut konsumennya.

2. Untuk mengetahui apakah konsumen puas setelah menggunakan jasa maskapai penerbangan Air Asia.

3. Untuk mengetahui seberapa tinggi minat beli konsumen untuk menggunakan jasa maskapai penerbangan Air Asia.

4. Untuk mengetahui pengaruh kualitas layanan terhadap kepuasan konsumen maskapai penerbangan Air Asia.

5. Untuk mengetahui pengaruh kualitas layanan terhadap minat beli konsumen untuk menggunakan jasa maskapai penerbangan Air Asia.

6. Untuk mengetahui pengaruh kepuasan konsumen terhadap minat beli konsumen untuk menggunakan jasa maskapai penerbangan Air Asia.

7. Untuk mengetahui pengaruh kualitas layanan terhadap minat beli konsumen untuk menggunakan jasa maskapai penerbangan Air Asia yang dimediasi oleh kepuasan konsumen.

\section{TINJAUAN PUSTAKA}

\section{A. Jasa}

Menurut Kotler dan Keller (2016:422) jasa adalah segala aktivitas atau berbagai kegiatan atau kinerja yang dari satu pihak yang ditawarkan kepada pihak lain yang pada dasarnya tidak berwujud dan tidak menghasilkan perpindahan kepemilikan apapun. Produksinya mungkin tidak terikat pada suatu produk secara fisik.Sedangkan menurut Kotler dan Amstrong (2012:248) jasa adalah bentuk suatu produk yang terdiri dari aktivitas, manfaat, atau kepuasan yang ditawarkan untuk dijual kepada pasar yang pada dasarnya tidak berwujud dan tidak 
menghasilkan kepemilikan terhadap apapun.

Lovelock dan Wirtz (2011:37) mengatakan jasa adalah kegiatan ekonomi yang ditawarkan dari suatu pihak ke pihak lain, seringkali berbasis waktu, kinerja yang dihasilkan memberikan hasil yang diinginkan oleh konsumen, objek, atau asset lain dimana pembeli memiliki tanggung jawab untuk jasa yang dihasilkan, dalam pertukaran untuk uang, waktu, dan upaya, pelayanan konsumen mengharapkan sebuah nilai dari kemampuan untuk mendapatkan akses untuk barang, pekerja, kemampuan professional, fasilitas, jaringan, dan sistem; akan tetapi konsumen tidak mendapatkan kepemilikan dari seluruh elemen fisik yang terlibat di dalam prosenya.

Dari pengertian para ahli tersebut, dapat disimpulkan pengertian jasa adalah kegiatan ekonomi yang menghasilkan kinerja tertentu yang ditawarkan dari satu pihak ke pihak lain, yang tidak berwujud, dan memberikan suatu manfaat tertentu akan tetapi tidak menghasilkan kepemilikan produk apapun dalam bentuk fisik.

Karakteristik jasa menurut Kotler dan Keller (2016:424) adalah tidak berwujud (intangibility), tidak dapat dipisahkan (inseparatibility), bervasiasi (variability), dan tidak dapat disimpan (perishability).
Kotler dan Keller

$(2016: 422)$ menyatakan bahwa terapat lima kategori bauran jasa yaitu barang berwujud murni, barang yang disertai jasa, campuran, jasa utama yang disertau barang dan jasa yang sangat kecil, dan jasa murni.

Terdapat juga kategori jasa menurut Lovelock dan Writz (2012:16) yaitu pemrosesan terhadap pelanggan (people processing), pemrosesan terhadap barang atau milik (possession processing), pemrosesan terhadap stimulus mental (mental stimulus processing), dan pemrosesan terhadap informasi (informational processing).

Menurut Lovelock dalam Tjiptono (2016:16) terdapat tujuh kriteria klasifikasi jasa, yaitu ;

1. Segmen pasar, jasa diklasifikasikan menurut segmennya yang terbagi atas konsumen akhir atau konsumen organisasional.

2. Tingkat keberwujudan. Jasa diklasifikasikan kedalam tiga golongan yaitu rented goods service (penyewaan produk tertentu), owned good service (peningkatan kinerja produk), nongoods service (pelayanan personal jasa yang bersifat intangible).

3. Keterampilan penyedia jasa, diklasifikasikan menjadi dua 
kategori yaitu professional dan non-profesional.

4. Tujuan organisasi jasa, dibedakan menjadi dua kategori yaitu profitable (komersial) ataupun non-profitable.

5. Regulasi, dibedakan menjadi dua kategori yaitu regulated dan nonregulated.

6. Tingkat intensitas karyawan, dibedakan menjadi dua kategori yaitu people based service dan equipment based service.

7. Tingkat kontak penyadia jasa, dibedakan menjadi high contact service dan low contact service.

Bauran pemasaran jasa terdiri dari 7P menurut Lovelock dan Wirtz (2012:44), yaitu product (produk), price (harga), place (tempat), promotion (promosi), people (orang), process (proses), dan pysichal evidence (bukti fisik).

\section{B. Kualitas Layanan}

Menurut Lovelock dan Wirtz (2012:404), kualitas layanan adalah ukuran dari seberapa baik tingkat pelayanan yang diberikan sesuai harapan pelanggan. Memberikan kualitas layanan berarti sesuai dengan harapan pelanggan secara konsisten. Hal ini didukung dengan pernyataan Kotler dan Keller (2016:422), kualitas layanan adalah keseluruhan dari fitur dan karakteristik sebuah produk atau layanan yang menghasilkan kemampuan untuk memuaskan kebutuhan yang telah dinyatakan oleh konsumen. Sedangkan menurut Tjiptono (2013:77), kualitas layanan memiliki fokus kepada pemenuhan kebutuhan dan keinginan pelanggan serta ketepatan penyampaiannya untuk mengimbangi harapan pelanggan. Secara garis besar kualitas layanan adalah kemampuan sebuah layanan melalui fitur dan karakteristiknya untuk dapat memuaskan kebutuhan konsumen.

Dalam kualitas layanan terdapat 5 dimensi umum yang menjadi tolak ukur untuk menilai baik atau buruknya sebuah kualitas layanan menurut Kotler dan Keller (2016:442), yaitu :

1. Kehandalan (reliability)

Kemampuan untuk melaksanakan jasa secara andal dan akurat sesuai dengan yang dijanjikan.

2. Daya Tanggap (responsiveness)

Kesedian dari penyedia jasa untuk membantu konsumen memberikan layanan tepat waktu yang menekankan pada perhatian penuh dan kesigapan perusahaan untuk dapat menangani permintaan, keluhan, dan penyampaian pertanyaan, dan masalah yang dihadapi konsumen.

3. Jaminan (assurance)

Merupakan kemampuan penyedia jasa menunjukkan kepercayaan dan 
keyakinan konsumen terkait dengan layanan yang diberikan.

4. Empati (emphaty)

Merupakan kondisi perusahaan memperhatikan dan memberikan perhatian pribadi kepada konsumen.

5. Bukti Fisik (tangible)

Penampilan fisik, peralatan, personel, dan bahan komunikasi yang digunakan dalam penyediaan jasa kepada konsumen.

\section{Kepuasan Konsumen}

Menurut Kotler dan Keller (2016:153), kepuasan konsumen adalah perasaan senang atau kecewa seseorang yang dihasilkan dari perbandingan atara kinerja produk yang dirasakan dengan kinerja yang diharapkan. Apabila kinerja yang dihasilkan tidak memenuhi harapan, maka konsumen akan merasa tidak puas. Namun, apabila kinerja yang melebihi harapan konsumen, maka konsumen akan merasa puas. Sedangkan menurut Oliver (1997:28), kepuasan konsumen adalah suatu keadaan dimana kebutuhan konsumen telah terpenuhi dan konsumen tersebut merespon dengan tingkat kepuasannya. Penigkatan kepuasan konsumen akan memiliki dampak pada pertumbuhan penjualan yang ditandai dengan adanya pembelian ulang. Pengertian kepuasan konsumen adalah dimana apa yang dibutuhkan oleh konsumen dapat terpenuhi dengan kinerja yang diberikan oleh produk atau jasa.

Menurut Irawan (2002:37) tedapat faktor yang mendorong kepuasan konsumen, yaitu :

1. Kualitas produk. Kualitas yang baik akan menghasilkan tingkat kepuasan yang tinggi.

2. Kualitas layanan. Konsumen akan merasa senang dan puas apabila layanan yang diberikan oleh perusahaan baik dan sesuai dengan yang mereka harapkan.

3. Harga. Harga murah merupakan sumber kepuasan terpenting bagi konsumen.

4. Faktor emosional. Kepuasan yang dirasakan konsumen juga menyangkut tentang harga diri dan nilai sosial yang memberikan nilai tambah bagi konsumen.

5. Biaya atau kemudahan. Kenyamanan dan efisiensi dalam mendapatkan produk atau jasa memberikan nilai kepuasan tersendiri bagi konsumen.

Menurut Oliver

(1997:124), pengukuran kepuasan konsumen mengacu pada tiga dimensi, yaitu :

\section{Expectation}

Merupakan sebuah prediksi dari atribut kinerja produk pada tingkat kinerja tertentu yang dinyatakan dalam tingkat probabilitas atau kemungkinan. 


\section{Disconfirmation}

Harapan yang dikonfirmasikan, secara teknis merupakan hasi perbandingan apa yang diharapkan dengan apa yang diamati

\section{Performance}

Tingkat kinerja yang diterima oleh konsumen dari beberapa atribut produk atau layanan, biasanya pada skala objektif dilaporkan tingkat baik atau buruk.

Menurut Kotler dan Keller (2016:155) terdapat beberapa metode untuk mengukur kepuasan konsumen, yaitu dengan survey berkala, analisa tingkat kehilangan konsumen, belanja misterius, dan melacak kinerja pesaing.

\section{Minat Beli Konsumen}

Menurut Thamrin dalam Dewi dan Nuryati (2014), minat beli konsumen adalah merupakan bagian dari komponen perilaku konsumen dalam sikap mengkonsumsi, kecenderungan responden untuk bertindak sebelum keputusan membeli benar-benar dilaksanakan. Perilaku konsumen dalam mengambil suatu keputusan pembelian mempertimbangkan barang dan jasa apa yang akan dibeli, dimana, kapan, bagaimana, berapa jumlah dan mengapa membeli produk tersebut. Simamora (2002:245) mengatakan, minat beli adalah sesuatu yang pribadi dan berhubungan dengan sikap. Individu yang berminat terhadap suatu objek akan mempunyai kekuatan atau dorongan untuk melakukan serangkaian tingkah laku untuk mendekati atau mendapatkan objek tersebut. Sedangkan menurut Assael dalam Sugiarto dan Subagio (2014), minat beli adalah perilaku yang muncul sebagai respon terhadap objek yang menunjukkan keinginan konsumen untuk melakukan pembelian. Berdasarkan pengertian beberapa ahli diatas, dapat disimpulkan minat beli konsumen adalah perilaku konsumen untuk mendapatkan suatu barang atau jasa, berdasarkan respon terhadap suatu objek yang didasari dengan keinginan kuat untuk mendapatkan barang atau jasa tersebut.

Tahapan minat beli konsumen menurut Suwandari dalam Rizky dan Yasin (2014), yaitu perhatian (attention) terhadap suatu barang atau jasa, dan akan menimbulkan minat (interest). Pada akhirnya minat tersebut akan menimbulkan keinginan (desire) yang berupa sebuah ketertarikan mendalam yang mendorong konsumen untuk mendapatkan barang atau jasa. Setelah itu konsumen akan melakukan tindakan (action) untuk mendapatkan barang atau jasa tersebut.

Terdapat 4 indikator minat beli konsumen menurut Ferdinand dalam Sugiarto dan Subagio (2014), yaitu :

1. Minat transaksional 
Kecenderungan seseorang untuk

membeli suatu produk atau jasa

2. Minat referensian

Minat seseorang untuk mereferensikan sebuath produk atau jasa kepada orang lain.

3. Minat preferensial

Minat yang menggambarkan perilaku seseorang yang memiliki sebuah preferensi utama dari sebuah produk atau jasa. Preferensi ini dapat diganti apabila terjadi sesuatu dengan produk preferensinya.

4. Minat eksploratif

Minat ini menggambarkan perilaku seseorang yang selalu mencari informasi mengenai produk atau jasa yang diminatinya.

Kerangka pemikiran dari penelitian ini dapat diilustrasikan sebagai berikut : 


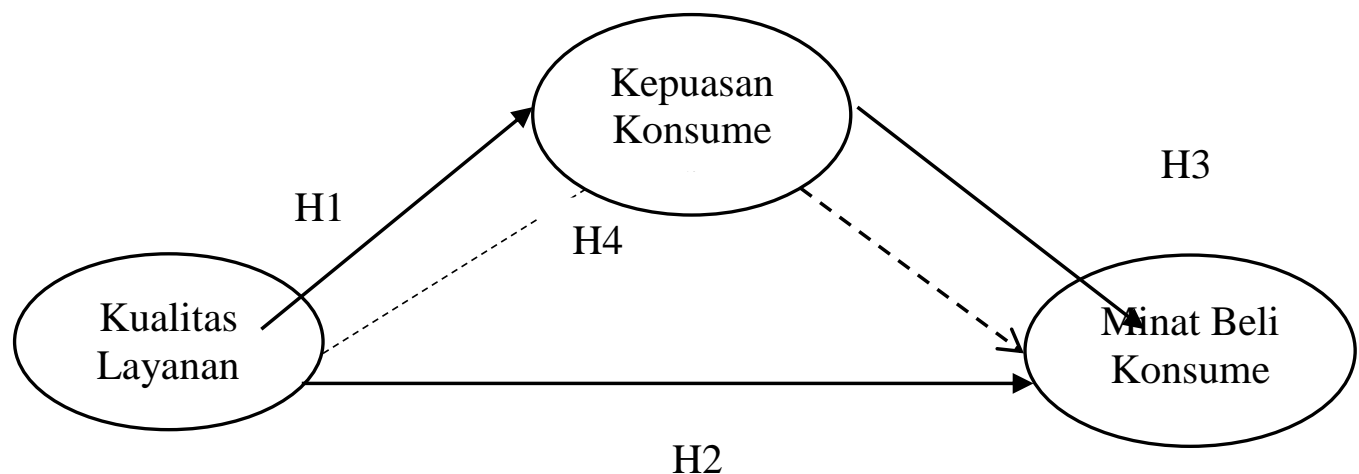

Hipotesis penelitian :

H1 : Kualitas layanan berpengaruh positif terhadap kepuasan konsumen.

$\mathrm{H} 2$ : Kualitas layanan berpengaruh positif terhadap minat beli konsumen.

H3 : Kepuasan konsumen berpengaruh positif terhadap minat beli konsumen.

H4 : Kualitas layanan berpengaruh positif terhadap minat beli konsumen yang dimediasi oleh kepuasan konsumen.

\section{METODE PENELITIAN}

Penelitian ini adalah penelitian kuantitatif, sampel yang digunakan dalam penelitian ini adalah responden yang pernah menggunakan jasa maskapai penerbangan Air Asia minimal satu kali. Teknik pengambilan sampel yang digunakan adalah non-probability sampling dengan pendekatan judgement sampling. Data diperoleh dengan

menyebarkan kuesioner secara elektronik menggunakan media google docs dan kuesioner konvensional secara tertulis kepada 150 orang yang pernah menggunakan jasa maskapai penerbangan Air Asia. Teknik analisis data yang digunakan dalam penelitian ini adalah SEM (Structural Equation Modeling) dengan menggunakan program Lisrel 8.80. Adapun analisis data yang digunakan meliputi analisis deskriptif, analisis ratarata, uji validitas dan reliabilitas, uji kecocokan keseluruhan model, uji persamaan struktural dan analisis pengaruh langsung dan tidak langsung.

\section{HASIL DAN PEMBAHASAN}

1. Dari analisis deskriptif yang dilakukan berikut adalah profil 150 responden yang berpartisipasi dalam penelitian ini : 
Tabel 1. Profil responden

\begin{tabular}{|c|c|c|c|c|}
\hline No. & $\begin{array}{l}\text { Profil Demografis } \\
\text { Responden }\end{array}$ & Kategori & Frekuensi & $\begin{array}{c}\text { Persentase } \\
(\%)\end{array}$ \\
\hline \multirow[t]{2}{*}{1} & \multirow{2}{*}{ Jenis Kelamin } & Laki-Laki & 63 & 42 \\
\hline & & Perempuan & 87 & 58 \\
\hline \multirow{5}{*}{2} & \multirow{5}{*}{ Usia } & $\leq 18$ tahun & 20 & 13,3 \\
\hline & & $19-29$ tahun & 107 & 71,3 \\
\hline & & $30-39$ tahun & 17 & 11,3 \\
\hline & & $40-49$ tahun & 1 & 0,7 \\
\hline & & $\geq 50$ tahun & 5 & 3,3 \\
\hline \multirow[t]{5}{*}{3} & \multirow{5}{*}{ Pekerjaan } & Pelajar / Mahasiswa & 80 & 53,3 \\
\hline & & Karyawan & 44 & 29,3 \\
\hline & & Wiraswasta & 8 & 5,3 \\
\hline & & Ibu Rumah Tangga & 5 & 3,3 \\
\hline & & Lainnya & 31 & 20,7 \\
\hline
\end{tabular}

Berdasarkan persentase dalam tabel tersebut dinyatakan bahwa responden yang memiliki usia antara 19-29 tahun menyumbang persentase yang cukup banyak dengan pekerjaan sebagai mahasiswa atau pelajar. Sedangankan yang menyumbang persentase terkecil adalah responden yang berusia 40-49 tahun dan dari segi pekerjaan adalah ibu rumah tangga.

2. Analisis rata-rata yang dilakukan memberikan gambaran dari keseluruhan variabel berdasarkan data yang dikumpulkan, adalah sebagai berikut :

Tabel 2. Analisis Rata-Rata

\begin{tabular}{lccc}
\hline \multicolumn{1}{c}{ Variabel } & Rata-rata & \multicolumn{2}{c}{ Selang Kepercayaan } \\
& 3.6562 & 3.5262 & Upper \\
Kualitas Layanan & 3.642 & 3.522 & 3.7881 \\
Kepuasan Konsumen & 3.5525 & 3.4075 & 3.6975 \\
Minat Beli Konsumen & & \\
\hline
\end{tabular}

Berdasarkan analisis tersebut kualitas layanan, kepuasan konsumen, dan minat beli konsumen berada pada rentang skala setuju pada skala likert yang memiliki interval antara 3,40-4,19 yang menyatakan bahwa kualitas layanan baik, kepuasan cukup tinggi, dan minat beli yang tinggi.

3. Uji Validitas dan reliabilitas dari keseluruh indikator pada masingmasing variabel adalah sebagai berikut 
Tabel 3. Validitas dan Reliabilitas Kepuasan Konsumen

\begin{tabular}{|c|c|c|c|c|c|}
\hline $\begin{array}{c}\text { Kode } \\
\text { Indikator }\end{array}$ & $\begin{array}{l}\text { Standardized } \\
\text { Loading } \\
\text { Factor }\end{array}$ & $\begin{array}{l}\text { Standard } \\
\text { Errors }\end{array}$ & t-value & Keterangan & $\begin{array}{c}\text { Reliabilitas } \\
\text { CR }\end{array}$ \\
\hline $\mathrm{R} 1$ & 0,73 & 0,46 & 10,23 & Valid & 0,92 \\
\hline $\mathrm{R} 2$ & 0,71 & 0,49 & 9,85 & Valid & \\
\hline R3 & 0,61 & 0,63 & 8,08 & Valid & \\
\hline D1 & 0,69 & 0,52 & 9,54 & Valid & \\
\hline D2 & 0,69 & 0,52 & 9,52 & Valid & \\
\hline D3 & 0,52 & 0,73 & 6,61 & Valid & \\
\hline A1 & 0,76 & 0,42 & 10,86 & Valid & \\
\hline $\mathrm{A} 2$ & 0,73 & 0,47 & 10,22 & Valid & \\
\hline A3 & 0,51 & 0,73 & 6,58 & Valid & \\
\hline E1 & 0,77 & 0,40 & 11,07 & Valid & \\
\hline E2 & 0,72 & 0,49 & 9,94 & Valid & \\
\hline E3 & 0,68 & 0,54 & 9,26 & Valid & \\
\hline E4 & 0,76 & 0,42 & 10,82 & Valid & \\
\hline $\mathrm{T} 1$ & 0,72 & 0,48 & 10,01 & Valid & \\
\hline $\mathrm{T} 2$ & 0,61 & 0,63 & 8,09 & Valid & \\
\hline $\mathrm{T} 3$ & 0,51 & 0,74 & 6,47 & Valid & \\
\hline $\begin{array}{c}\text { Kode } \\
\text { Indikator }\end{array}$ & $\begin{array}{c}\text { Standardized } \\
\text { Loading } \\
\text { Factor }\end{array}$ & $\begin{array}{c}\text { Standard } \\
\text { Errors }\end{array}$ & t-value & Keterangan & $\begin{array}{c}\text { Reliabilitas } \\
\text { CR }\end{array}$ \\
\hline KP1 & 0.77 & 0.4 & $* *$ & Valid & 0,87 \\
\hline KP2 & 0.81 & 0.34 & 10.44 & Valid & \\
\hline KP3 & 0.74 & 0.45 & 9.37 & Valid & \\
\hline KP4 & 0.75 & 0.44 & 9.47 & Valid & \\
\hline KP5 & 0.77 & 0.4 & 9.87 & Valid & \\
\hline
\end{tabular}

Tabel 4. Validitas dan Reliabilitas Minat Beli Konsumen

\begin{tabular}{cccccc}
\hline $\begin{array}{c}\text { Kode } \\
\text { Indikator }\end{array}$ & $\begin{array}{c}\text { Standardized } \\
\text { Loading } \\
\text { Factor }\end{array}$ & $\begin{array}{c}\text { Standard } \\
\text { Errors }\end{array}$ & t-value & Keterangan & Reliabilitas \\
MI1 & 0.85 & 0.27 & $* *$ & Valid & CR \\
MI2 & 0.88 & 0.23 & 13.35 & Valid & \\
MI3 & 0.79 & 0.37 & 11.52 & Valid & \\
MI4 & 0.66 & 0.56 & 8.9 & Valid & \\
\hline
\end{tabular}

Dari pengujian validitas dan reliabilitas seluruh indikator memiliki standardized loading factor diatas 0,50 dan $t$-value $>1,96$ sehingga dinyatakan valid. Dari penguian reliabilitas seluruh variabel memiliki CR diatas 0,70 sehingga dinyatakan reliabel. 
4. Analisis Kecocokan Keseluruhan Model (Goodness of Fit)
Dari pengujian kecocokan

keseluruhan model diperoleh hasil

sebagai berikut:

Tabel 5. Analisis Kecocokan Keseluruhan Model

\begin{tabular}{|c|c|c|c|}
\hline Ukuran GOF & $\begin{array}{c}\text { Kriteria tingkat } \\
\text { Kecocokan }\end{array}$ & Hasil Estimasi & Tingkat Kecocokan \\
\hline $\begin{array}{l}\text { Chi Square } \\
\mathrm{P} \text { value }\end{array}$ & $\begin{array}{l}\text { Nilai yang kecil } \\
p>0,05\end{array}$ & $\begin{array}{l}X^{2}=534,33 \\
(p=0,00)\end{array}$ & Kurang Baik \\
\hline NCP Interval & $\begin{array}{l}\text { Nilai yang kecil dan } \\
\text { interval yang sempit }\end{array}$ & $\begin{array}{l}262,33 \\
(200,53: 331,92)\end{array}$ & Kurang Baik \\
\hline $\begin{array}{l}\text { RMSEA } \\
\text { P value (close fit) }\end{array}$ & $\begin{array}{l}\text { RMSEA } \leq 0,08 \\
p \geq 0,50\end{array}$ & $\begin{array}{l}0,08 \\
(p=0,0)\end{array}$ & Baik (good fit) \\
\hline ECVI & $\begin{array}{l}\text { Nilai yang kecil dan } \\
\text { dekat dengan ECVI } \\
\text { saturated }\end{array}$ & $\begin{array}{l}\mathrm{M}^{*}=4,30 \\
\mathrm{~S}^{*}=4,36 \\
\mathrm{I}^{*}=64,86\end{array}$ & Baik (good fit) \\
\hline AIC & $\begin{array}{l}\text { Nilai yang kecil dan } \\
\text { dekat dengan AIC } \\
\text { saturated }\end{array}$ & $\begin{array}{l}M^{*}=640,33 \\
S^{*}=650,00 \\
I^{*}=9664,63\end{array}$ & Baik (good fit) \\
\hline CAIC & $\begin{array}{l}\text { Nilai yang kecil dan } \\
\text { dekat dengan CAIC } \\
\text { saturated }\end{array}$ & $\begin{array}{l}\mathrm{M}^{*}=852,90 \\
\mathrm{~S}^{*}=1953,46 \\
\mathrm{I}^{*}=9764,90\end{array}$ & Baik (good fit) \\
\hline NFI & $\mathrm{NFI} \geq 0,90$ & 0,94 & Baik (good fit) \\
\hline NNFI & $\mathrm{NNFI} \geq 0,90$ & 0,96 & Baik (good fit) \\
\hline CFI & $\mathrm{NFI} \geq 0,90$ & 0,97 & Baik (good fit) \\
\hline IFI & $\mathrm{IFI} \geq 0,90$ & 0,97 & Baik (good fit) \\
\hline RFI & $\mathrm{RFI} \geq 0,90$ & 0,93 & Baik (good fit) \\
\hline RMR & $\begin{array}{l}\text { Standardized RMR } \\
\leq 0,05\end{array}$ & 0,59 & Kurang Baik \\
\hline GFI & $\mathrm{GFI} \geq 0,90$ & 0,76 & Kurang Baik \\
\hline AGFI & $\mathrm{AGFI} \geq 0,90$ & 0,73 & Kurang Baik \\
\hline
\end{tabular}

Dari analisis kecocokan keseluruhan model tersebut dilakukan 14 pengukuran untuk model penelitian ini. Dari ke-14 pengukuran tersebut terdapat 5 pengukuran yang menyatakan kecocokan model kurang baik sedangkan 9 lainnya menyatakan bahwa kecocokan keseluruhan model adalah baik. Hal tersebut menyatakan bahwa model yang digunakan dalam penelitian ini belum sepenuhnya sempurna.

5. Uji Pada Model Struktural

Dari hasil pengolahan data yang dilakukan pengujian persamaan model struktural oleh program lisrel 8.80 adalah sebagai berikut : 


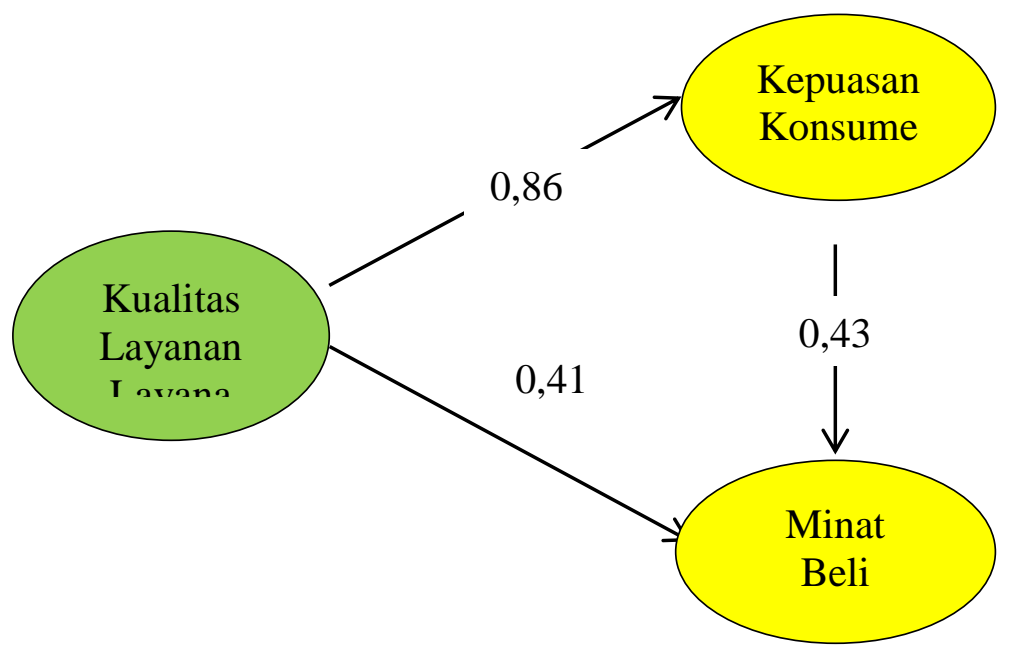

Dari hasil pengujian model struktural tersebut dapat dilihat bahwa kualitas layanan memiliki pengaruh langsung sebesar 0,86 terhadap kepuasaan konsumen dan memiliki pengaruh langsung sebesar 0,41 terhadap minat beli konsumen. Sedangkan kepuasan konsumen memiliki pengaruh langsung sebesar 0,43 terhadap minat beli kosumen. Nilai t-value pada pengujian pengaruh langsung kualitas layanan terhadap kepuasan konsumen adalah 9,39. Nilai t-value pada pengujian pengaruh langsung kualitas layanan terhadap kepuasan konsumen adalah 2,72. Nilai t-value pada pengujian pengaruh langsung kualitas layanan terhadap minat beli konsumen adalah 2,77. Hasil tersebut menunjukkan bahwa Kualitas layanan terbukti memiliki pengaruh langsung terhadap kepuasan konsemun dan minat beli konsumen, demikian juga kepuasan konsumen terbukti memilik pengaruh langsung terhadap minat beli konsumen.

6. Analisis pengaruh langsung dan tidak langsung dari keseluruhan model penelitian dijabarkan dalam tabel berikut :

Tabel 6. Analisis Pengaruh Langsung dan Tidak Langsung

\begin{tabular}{|c|c|c|c|c|c|c|}
\hline \multirow{3}{*}{ Variabel } & \multicolumn{6}{|c|}{ Pengaruh } \\
\hline & Lang & ung & Tidak Le & ngsung & TOT & $\mathbf{A L}$ \\
\hline & $\begin{array}{l}\text { Koefisien } \\
\text { Jalur }\end{array}$ & T-value & $\begin{array}{l}\text { Koefisien } \\
\text { Jalur }\end{array}$ & T-value & $\begin{array}{l}\text { Koefisien } \\
\text { Jalur }\end{array}$ & T-value \\
\hline $\begin{array}{l}\text { Kualitas layanan } \rightarrow \\
\text { Kepuasan Konsumen }\end{array}$ & 0,86 & 9,39 & - & - & 0,86 & 9,39 \\
\hline $\begin{array}{l}\text { Kualitas layanan } \rightarrow \\
\text { Minat Beli Konsumen }\end{array}$ & 0,41 & 2,72 & 0,37 & 2,76 & 0,78 & 9,28 \\
\hline $\begin{array}{l}\text { Kepuasan Konsumen } \rightarrow \\
\text { Minat Beli Konsumen }\end{array}$ & 0,43 & 2,77 & - & - & 0,43 & 2,77 \\
\hline
\end{tabular}


Dari tabel tersebut dapat dilihat bahwa terdapat pengaruh tidak langsung antara kualitas layanan terhadap minat beli konsumen melalui kepuasan konsumen sebesar 0,37 dan menghasilkan pengaruh total sebesar 0,78 .

\section{Pembahasan}

1. Hipotesis 1 menyatakan bahwa terdapat pengaruh positif antara kualitas layanan terhadap kepuasan konsumen. Hasil dari penelitian ini menyatakan bahwa terdapat pengaruh sebesar 0,86 antara kualitas layanan dan kepuasan konsumen dengan nilai $t$-value sebesar 9,39> 1,96. Hal tersebut menyatakan bahwa kualitas layanan memiliki pengaruh sebesar $86 \%$ terhadap kepuasan konsumen dan sisanya dipengaruhi oleh variabelvariabel lain. Hal ini menyatakan bahwa kualitas layanan memiliki pengaruh yang positif dan signifikan terhadap kepuasan konsumen. Dengan kata lain semakin baik suatu kualitas layanan maka kepuasan konsumen akan semakin tinggi.

2. Hipotesis 2 menyatakan terdapat pengaruh antara kualitas layanan dengan minat beli konsumen. Hasil dari penelitian ini menyatakan bahwa kualitas layanan memiliki pengaruh sebesar 0,41 secara langsung terhadap minat konsumen dengan t-value sebesar 2,72 > 1,96. Hal ini menyatakan bahwa kualitas layanan memiliki signifikansi sebesar $41 \%$ terhadap minat beli konsumen. Dengan kata lain jika kualitas layanan baik maka minat konsumen akan semakin tinggi dan begitu juga sebaliknya.

3. Hipotesis 3 menyatakan terdapat pengaruh positif antara kepuasan konsumen berpengaruh dengan minat beli konsumen. Hasil dari penelitian ini menyatakan bahwa terdapat pengaruh sebesar 0,43 antara kepuasan konsumen dengan minat beli konsumen dengan $t$-value sebesar 2,77 $>$ 1,96. Hal ini menyatakan bahwa terdapat signifikansi sebesar $43 \%$ antara kepuasan konsumen dan minat beli konsumen. Dapat dikatakan bahwa jika konsumen merasa puas maka konsumen akan memiliki minat yang lebih tinggi untuk pembelian selanjutnya.

4. Hipotesis 4 menyatakan terdapat pengaruh antara kualitas layanan terhadap minat beli konsumen yang dimediasi oleh kepuasan konsumen. Dar hasil penelitian tersebut dinyatakan bahwa terdapat pengaruh tidak langsung antara kualitas layanan dengan minat konsumen sebesar 0,37 
dan pengaruh total keseluruhan sebesar 0,78 dengan t-value sebesar 9,28 . Hal ini menyatakan bahwa terdapat signifikansi sebesar $37 \%$ pengaruh dari kualitas layanan terhadap minat konsumen secar tidak langsung melalu variabel kepuasan dengan keseluruhan signifikansi sebesar $78 \%$.

\section{SIMPULAN DAN SARAN}

\section{Simpulan}

Dari hasil penelitian ini disimpulkan bahwa maskapai penerbangan Air Asia memiliki kualitas yang baik. Maskapai Penerbangan Air Asia mampu memberikan kepuasan bagi konsumen yang menggunakan jasa penerbangannya. Maskapai Air Asia juga menarik minat yang tinggi dari para konsumennya untuk menggunakan jasanya. Selain itu juga dapat dibuktikan bahwa terdapat pengaruh yang positif dan signifikan antara kualitas layanan dengan kepuasan konsumen. Dibuktikan juga terdapat pengaruh yang positif dan signifikan antara kualitas layanan dengan minat beli konsumen secara langsung. Hal tersebut berarti apabila kualitas layanan baik maka akan menciptakan kepuasan dan minat beli konsumen yang tinggi juga. Dibuktikan juga bahwa terdapat pengaruh yang positif dan signifikan antara kepuasan konsumen dengan minat beli konsumen. Selain itu juga ditemukan bahwa terdapat pengaruh 16 yang positif dan signifikan antara kualitas layanan terhadap minat beli konsumen yang dimediasi oleh kepuasan konsumen. Dengan demikian dapat disimpulkan bahwa kepuasan konsumen memiliki peran positip dalam memediasi pengaruh kualitas layanan terhadap minat beli konsumen.

\section{Saran}

Meskipun kualitas layanan yang diberikan oleh Masakapai penerbangan Air Asia sudah baik, namun sebaiknya peningkatan kualitas harus tetap dijaga dan ditingkatkan. Terutama pada hal ketepatan waktu penerbangan dan keselamatan penumpang. Kedua hal ini harus lebih diperhatikan. Manajemen maskapai penerbangan Air Asia juga harus lebih tanggap terhadap kebutuhan konsumen untuk meningkatkan kepuasan konsumen. Program promo yang dilakukan oleh Air Asia sudah baik, namun sebaiknya publikasi dari promo yang dilakukan harus lebih gencar untuk dapat menarik lebih banyak konsumen.Manajemen harus lebih baik lagi dalam menjaga kepuasan konsumennya dengan cara menjalin hubungan yang baik dengan konsumennya dengan memperhatikan apa yang konsumen butuhkan. Untuk penelitian selanjutnya diharapkan melakukan penelitian yang lebih kompleks dan menambahkan beberapa variabel-variabel untuk mendapatkan fakta-fakta baru. 


\section{DAFTAR PUSTAKA}

Dewi, C. dan Nuryati. 2014, Pengaruh Kualitas Pelayanan terhadap Kepuasan dan Minat Beli di Konsumen Rumah Makan Boga-Bogi di Surakarta.

Handayani, SB., Setya Irianto. 2011, Pengaruh Kualitas Layanan dan Tari terhadap Kepuasan serta Implikasinya terhadap Minat Beli Pasien Rawat Inap pada Rumah Sakit Roemani Muhammadiyah Semarang.

Kotler, P. dan. Amstrong, G.M.. 2011, Principles of Marketing, Edisi ke-14, USA : Prentice Hall.

Kotler, Philip dan Kevin Lane Keller. 2016, Marketing Management, Edisi ke-15e, Global Edition, USA : Pearson.

Lovelock, C. dan Wirtz, J. 2012, Services Marketing, Edisi ke-7, USA : Pearson.
Oliver, L. Richard. 1997, Satisfaction : A Behavioural Perspective on Consumer, Edisi ke-2, USA : McGraw-Hill.

Rizky, NST, Fakhru, M. dan Yasin, H. 2014, Pengaruh Promosi dan Harga terhadap Minat Beli Perumahan Obama PT. Nailah Adi Kurnia SEI Mencirim Medan.

Simamora, B. 2002, Panduan Riset Perilaku Konsumen, Surabaya : Pustaka Utama.

Sugiarto, B. U. dan Subagio, H. 2014, Analisa Pengaruh Produk, Kualitas Pelayanan, Harga, dan Store Atmosphere terhadap Minat Beli di Dream of Kahyangan Art Resto, Surabaya, Jurnal Manajemen Pemasaran Petra, Vol. 2, No.1.

Tjiptono, F. dan Chandra, G. 2016, Service, Quality, dan Satisfaction, Edisi ke-4, Yogyakarta : Penerbit Andi. 
